\title{
Democracy without Politics: Why Democracy Can Seriously Harm Democracy
}

\author{
Daniel Innerarity \\ Correspondence: University of Basque Country, Ikerbasque Foundation for Science, Spain.
}

Received: September 17, 2017

doi:10.11114/smc.v5i2.2697
Accepted: October 11, $2017 \quad$ Online Published: October 12, 2017

URL: https://doi.org/10.11114/smc.v5i2.2697

\begin{abstract}
The main argument of this paper is directed against the thesis that we are in a post-democratic era. I consider that we are rather in a post-political era, that is to say, one in which the demands expressed in moments of democratic explosion do not often find a political channel that translates them into effective transformations. To this is added the fact that some of the current forms of activism have given rise to what could be called an "intermittent citizenship" that has seduced some with the possibility of establishing that negative sovereignty at the core of the construction of the general will, which has depolitizing effects. This is the context in which the great rift between technocratic reasons and populist reasons has been constituted. I end up defending a concept of "indirect democracy" or "complex democracy" that attempts to politically integrate both moments.
\end{abstract}

Keywords: democracy, citizenry, indignation, depoliticization, indirect democracy, populism, negative souverain

\section{Introduction}

The dominant narrative affirms that we live in a post-democratic age (Crouch 2004). This denouncement comes in various forms, such as the superiority of the executive over the legislative branch (Habermas 2013), the distancing of the elite from those who are governed, the displacement of the parties toward a center that eliminates choices (Mouffe 2013), a lack of consideration for what society really wants... That is not the way I see it. The precaution that is learned when one is barely capable of anything other than philosophical suspicion leads me to look at things differently. Could it not be that we have democracy that is open and politics that are weak? Democracy is an open space where, in principle, anyone can make his or her opinion known, which makes a thousand types of pressure possible, and we even have the ability to remove governments. This works relatively well. In our democratic societies, there is no lack of open spaces of influence and mobilization, social networks, protest movements, demonstrations, possibilities for intervention and obstruction.

What is not going so well is politics, in other words, the possibility of converting this plural aggregate of forces into projects and political transformations, giving direction and political coherence to those popular expressions and configuring quality public spaces where everything is deliberated, discussed, and synthesized. The fact that it is increasingly difficult for those who act politically to formulate alternative agendas has something to do with this. We are in a post-political era, an era of democracy without politics, which Rosanvallon has called "impolitic democracy" (2006). People are aggravated and the political system is agitated, but their interaction barely produces anything new, as we would have the right to expect, given the nature of the problems that we must confront.

I am going to briefly examine the workings of this "negative sovereign" that has become a force that is as strong as it is ambiguous. I will attempt to reconstruct the ideological assumptions of those who have celebrated this phenomenon as a triumph over politics in its traditional form (but which I interpret instead as an attempt to triumph over politics in and of $i t s e l f)$. One of the most disagreeable effects of this democratic vitality is that it depoliticizes the public space, a phenomenon that can be seen in certain concepts that have recently been all the rage following the crisis of representative democracy. There is a demand for direct or plebiscitary democracy, an expectation that citizen participation will grant us things that cannot be obtained from representative delegation, confidence that the establishment of transparency as a universal principle will fix everything. Based on these assumptions, the progress of populism is not the solution, but neither is it merely a problem; it is instead a symptom of the fact that we have not yet properly considered the place of democracy in a political society. We will only be able to overcome some of these failures if we engage in a critique of depoliticized democracy or, to formulate it in a positive fashion, a defense of politics against depoliticized democracy. 
Democracy can seriously harm democracy not only because democratic procedures allow those who are interested in destroying its power to access it, but also in a less obvious sense: certain procedures that are irreproachably democratic, if not correctly articulated, can damage democratic quality. Given that they are defended in the name of democracy and we have no intuitive sense of danger when they are demanded, what harm is there in promoting more participation, in carrying transparency to the extreme, in governing based on opinion polls, in increasing consultation, in always doing what the people want, in presuming that the closest thing is necessarily the most democratic? Politics is especially vulnerable to this type of demand. We will only be able to combat the things that are apparently democratic if we point out how they can have anti-political effects if they are not integrated into a balanced understanding of politics. That is why I will conclude with a defense of what we could call indirect democracy, a territory that deserves to be explored, even when it does not make the direct forms of democratic intervention superfluous.

\section{An Intermittent Citizenry}

Experts say that the decrease in electoral participation is not accompanied by a lack of interest in the public space (Dalton 2004, 191). Citizens are avoiding classical types of organization, which is compatible with growing modalities of individual commitment, an activism that is not ideologically articulated in an ideological framework that affords coherence and totality, as could be the case with traditional, all-encompassing ideologies. The new activism is individualist, isolated, oriented toward questions that refer to lifestyles and increasingly apolitical growth (Norris 2002, 188). It is true that "the proliferation of opportunities for individual access to government has substantially reduced the incentives for collective mobilization" (Crenson / Ginsberg 2002, 2-3). In order to fully understand this new situation, we should abandon the simplistic framework that contrasts classical activism with apolitical indifference. As various scholars have suggested, the people who seem most indifferent to politics in its traditional format are the most committed in alternative or extra-parliamentary arenas. They often believe that their non-participation in elections is a markedly political decision (O'Toole / Marsh / Jones 2003).

The very shape of political activism is changing. The possibilities of exercising what Pierre Rosanvallon has called "counter-democracy" (2006) have increased because of citizens' self-awareness and technological advances. It is significant that most of the new political questions raised in the last thirty years have been furthered more by demonstrations and direct action than by conventional political activities through parties and parliaments (Budge 1996, 192). During the first half of the last century, the activities of civil society took place in the arena surrounding political institutions, but currently they are at a distance from the places of power. We live in a society that no longer seeks to constitute power in order to configure social processes; rather, it aims to prevent an abuse of power. Contemporary society prefers present transparency over future responsibility and exercises the distrust of the negative sovereign. We have not achieved the "optimal level of distrust" (Dahlgreen 2013, 17), and its excessive levels have made it a creator of anti-political distance.

What both the mobilizations on the internet as well as more classical protests in physical spaces have in common is their isolated and negative nature (not in a moral sense, but in the sense of principally aiming to prevent something). They are, for that reason, apolitical acts, to the extent that they are not inscribed in complete ideological constructions or in any long-lasting structure of intervention. Political activity today generally appears in the form of a mobilization that barely produces constructive experiences, is limited to ritualizing certain contradictions against those who govern, and they in turn react by simulating dialogue and doing nothing. The nature of political compromise is generally episodic. People want to be implicated in the political process but with the terms that they choose, which are intermittent, partial, and sporadic (Hibbing / Theiss-Morse 2002).

Digital space has opened new possibilities for political activism. Platforms for mobilization around concrete causes - such as Change or Avaaz - allow the exercise of concrete "clicktivism" in favor of good causes; this contrasts with following abstract ideologies that are the object of general incredulity. For broad sectors of the population, the reality represented by the hierarchical parties is no longer attractive, while the internet's virtual culture allows them to comfortably articulate their fluid and intermittent political dispositions and even take themselves off-line at any time.

Another manifestation of the new political mobilization has to do with the consumer world, increasingly employed to express political preferences. This activism has increased enormously since the mid-1980s (Pattie / Seyd / Whiteley 2003). The OECD reports that the annual value of the global market of "fair trade" products was 700 million dollars in 2003 (Vihinen / Lee 2004). This type of mobilization reveals the emergence of a new lifestyle in which informed citizens make decisions through which the fragmented masses can express themselves politically.

There are numerous examples of activism and "negative sovereignty" in the physical space as well. This is now also connected to digital mobilization: demonstrations and performances that gained a certain degree of celebrity, such as alternative forums at world summit meetings, Occupy Wall Street, "We are the 99\%," the entire 15-M movement in Spain, demands against housing evictions, protests against the privatization of public services, the intervention of 
individual accusations in judicial trials, the successful resistance against certain public works and infrastructures: from Burgos to Stuttgart passing through Nantes.

I am not questioning the value of these acts of civic resistance or on-line campaigns; I am simply pointing out that, since they are not inscribed into any political framework that gives them coherence, they can seem to imply that good politics is a mere aggregation of social accomplishments. The articulation of social demands in coherent programs that compete in a quality public sphere does not work; in short, there is a breakdown in the political and institutional construction of democracy beyond the emotion of the moment, beyond immediate pressure and media attention.

Of course, when we demand something that strikes us as fair do not need to require that it be accompanied by a complete political program and an economic memory. But the public space cannot be reduced to the mere apolitical accumulation of incoherent preferences, grouped together as if there was no priority and even certain incompatibilities among them. Someone should be in charge of organizing these demands with political criteria and managing any possible incompatibilities in a democratic fashion. But, is there anyone there? If politics (and the parties that are so despised) are good for anything, it is precisely to integrate the multiple demands that continuously arise in the space of an open society with democratic coherence and authority. The construction of infrastructures is blocked, and they probably should not be built anyway, or at least not in that fashion, but we still do not know what should be done regarding infrastructures; we stop the evictions - because we can and should do so-but that in and of itself does not incentivize credit and make housing policies more fair; we can stop the privatization of public hospitals, but that does not determine the type of medical policy that should be in place. The politics I miss are the kind that begin when society's good reasons come to an end, where the task of the negative sovereign ends and the responsibility of the positive sovereign begins.

In addition to the fact that social demands are disarticulated, we add the circumstance that such demands are of course plural and at times incompatible or contradictory: some people want more taxes and others less, some free software and others protection of privacy and property, some are concerned that there are less freedoms and others that there are too many immigrants... Without political assessment, it is difficult to know when we are confronting an obstruction of necessary reforms or a protest against representational abuse. Protests against certain infrastructures can be motivated by ecological beliefs, but also by other beliefs that are less easily acknowledged, such as the famous NIMBY ("Not in My Back Yard") or by xenophobic sentiments if the proposal is to build a mosque. In any case, those who tend to celebrate social spontaneity should be reminded that society is not the kingdom of good intentions. The legitimacy of society's ability to criticize its representatives does not mean that those who criticize or protest are necessarily right. Being indignant or a critic or victim does not make anyone politically infallible.

It is true that the difference between the representatives and the represented is too large, and they are criticized for this distance, often justifiably. There are demands that politicians listen to the people, which is an unassailable recommendation, but we must also understand that citizens rarely share the same demands, desires, and interests. The political system is continuously bombarded by different types of demands. The difficulty consists of needing to accept some demands and reject others because of the limitation of resources, impracticality, equity, the defense of certain less outspoken social groups or the rights of future generations. And it often turns out that what people say they want and what they are willing to allow politicians to do are two very different things: people want to combat climate change but may not want to modify their lifestyle, they want better services but they do not want to pay higher taxes, they would like cheaper labor costs but are not willing to accept more immigrants...

There is another phenomenon of anti-political social resistance that deserves special attention. I am referring to the fact that "tea parties" have formed around or at the extremes of the parties. They present themselves as protectors of values, representatives of victims, spokespersons for the crowd or for some upcoming revolution. From these apolitical trenches, they seem to master things with a clarity not available to those who regularly deal with the principle of reality. The wrath of these groups is directed less at adversaries than at their own side when they show signs of decreasing the number of things that are politically non-negotiable. They spread an anti-political mentality because they have not understood that politics always entails certain compromises and concessions. The extreme wings of the parties set the tone to an extent that is probably not their due. They determine criteria for representativeness without having the corresponding democratic authority. This makes certain reforms that require negotiation with one's political adversaries more difficult.

\section{The Ideology of the Negative Sovereign}

At the ideological extremes, there is a contempt for politics that is in no way a criticism of a concrete way of doing politics but is, instead, a total rejection of politics, the profound desire that politics should not exist, or that it be, at most, irrelevant. The political space of democracies is besieged, on the right and on the left, by extreme forms of resistance against politics, which some people exercise from the market and others from society, both of them-market and 
society-understood as realities extraneous to the political process, from the autonomy of self-regulated markets, in the first case, or from the sovereignty of a society constituted at the margins of the procedures of institutional representation. Financial neoliberalism and "wikicommunism" share a similar distrust of politics, while they celebrate "the wisdom of the masses," as market agents or as members of the crowd. At heart, the illusion of a self-governed society without institutional and juridical mediations is barely distinguishable from the liberal myth of the self-regulation of the markets. We already knew that neoliberalism is an anti-political ideology, but we should not lose sight of the fact that, at the other extreme of the ideological spectrum, there are attitudes that have similar effects.

For that reason, I am going to focus more on the non-social democratic left, because the liberal right's indifference to politics is more obvious. Today's dominant political theory in this realm conceives of popular sovereignty as something external to the institutional political system, very similar to the forms of pre-modern resistance against authority; it is not seen to be actively implicated in the procedures of representative politics. Constituent power inevitably has an anti-institutional dimension. That is why they emphasize conferences, occupations, protests, and movements in which they appear to exercise truly anti-establishment power and stage forums of "true democracy." In this way, they are searching for an immediate efficacy of popular will, which could only exist politically in negative and anti-political terms. Society is not structured by the right and by politics, but by sentiments and convictions.

Interpreted in this way, with this anti-institutional scorn, protests are limited to staging a moment of democratic sovereignty without practical structural repercussions. We can see in this a certain mythology of "pouvoir constituant" [constituent power] as a crowd, resistance, conflict, expression of democratic antagonism, a left-wing that, rather than advocating a concept of political intervention, is limited to radical gestures and an aestheticization of politics. One of the most curious factors in the current non-social democratic left's thinking is the adoption of certain elements of Carl Schmitt's political theory and its resignation in the face of dominant social structures. The citizenry is considered sovereign in resistance and in exceptional cases, but not in democratic normality (which makes it seem destined to hand the management of that normality over to the right).

The other thing that is curious about many of the current political theories of the alternative left is that they offer an involuntary ideological justification for deregulation. The radical democratic conception collaborates in consecrating the excommunication of a politics understood as the administration of objectivity and a society mobilized negatively, the normality of constituted power and the exceptionality of constituent power. The more the ethical value of resisting politics is emphasized, the fewer obstacles dominant politics finds against constituting itself as the only possible objectivity. In this way, a division of labor is established between bureaucratic politics and isolated politicization. In spite of what is sought by those who demand an agonistic vision of politics (Laclau / Mouffe 1991), this framework does not make the construction of transformative alternatives possible, but turns protests into something politically irrelevant, to the satisfaction of those who want politics to continue as is.

A curious "division of labor" regarding depoliticizing politics has taken place between those who, on the one hand, defend a technocratization of politics and, on the other, those who celebrate forms of social protest as something external to the political system. The most extreme versions of the right and the left collaborate in this way in the depoliticization of politics when they coincide in scorning its logic. One side seems unaware that it is not a technical question or the antiseptic handling of an unquestionable objectivity; the other seems to have forgotten its pragmatic and institutional dimension. There is a tacit division of territory, shaped by the arrogance of the first group and the resignation of the second.

The marriage between neoliberalism and radical democracy has other chapters. Many of those who mobilize against certain large infrastructures, for example, believe in non-ideological objectivities and brandish arguments that they attempt to enhance by presenting them, just as the technocrats have always done, as if they were above politics. Facts, common sense and popular indignation point in an unanswerable direction. They have little comprehension of how the logic of the political system works. Within it, the questions that are aired are not limited merely to truth and objectivity, but have to do with power relationships, irrationalities, risky bets, cognitive uncertainty, and ideological proposals. It is curious how both sides of the ideological spectrum have a similar conception of politics (or rather, of a society without politics) according to which, everything comes down to giving decision-making capabilities to those who claim to have privileged access to objectivity.

So then, who will put an end to capitalism? Well, the truth is that, in spite of the dominant rhetoric, there are no true enemies of capitalism who can be taken seriously, precisely at a time when they would be more necessary than ever. The recent spread of capitalism has caused many victims, but victim status does not in and of itself turn anyone into a political actor. Social injustices do not by themselves engender the conversion of suffering into a transformative force. There are many disadvantaged groups, but they are fragmented and one of the things that is missing is a narrative on the left that articulates them politically. 
Let us admit it: the crisis of financial capitalism and the erosion of its legitimacy are not the consequence of harsh attacks by social movements or the political left, but the result of an implosion stemming from its own contradictions. And while its legitimacy will be damaged, it will most likely emerge victorious, assuming no political force appears that can force it to transform.

\section{Involuntary Depoliticization}

The great challenge of current democratic societies is to not leave its representatives alone. It should monitor, criticize and, if it comes down to it, replace them, but without destroying or depoliticizing the public space. It is clear that we have not managed this balance, and we either abandon ourselves blindly to the competence of those who represent us (as, for different motives, the technocrats and populists want), or we reduce the trust and amount of delegation to such an extent that we subject politics to the register of immediacy (which also has both a technocratic version, of immediate efficacy, and a populist one, as government by survey, politics subjected to public opinion polls). In both cases, social activism can have depoliticizing effects to which we must pay special attention, because they are not obvious. What is obvious, what is politically correct, is understanding representation as a falsification, assuming that those who protest are right or presuming that the more participation and transparency there is, the better.

There is a way of understanding democracy that reaffirms itself as a battle against institutionalized or representative politics but that simultaneously destroys the spaces that are necessary to political life. This indirect depoliticization can be corroborated in the current crisis of representation. We can see good examples of it in certain demands for direct and plebiscitary democracy or the appeals for participation and transparency when they stop being corrective procedures for representative democracy and present themselves as candidates for overcoming it.

Let us begin with the crisis of representation, so frequently invoked lately, but which indeed forms part of political normality. There has always been debate in democratic societies about the nature of representation. A democratic society cannot set its procedures for representation in stone-such procedures are always debatable and improvable - but it slips toward the sphere of the anti-political when what it challenges is the very fact of representation.

Representation allows us to guarantee the plurality of the political, which does not happen with direct democracy. In a complex and differentiated society, only representation manages to allow a plurality of subjects to act without annulling that plurality. In this sense, representation is not an inconvenience, but the ability for society to act politically while simultaneously guaranteeing that diversity is maintained. If there is political representation, it is because we must simultaneously maintain the pluralism of society and its capacity to act, the demos and the cratos of democracy.

There is no other formula that guarantees effectiveness, pluralism and fairness better than representative democracy (which does not mean that it is always achieved or is not manifestly improvable). All the other forms of democratic intervention tend to do much worse. For some time now, we have been fantasizing about types of direct democracy, but their representativeness is much more debatable than our current electoral systems and their effectiveness at decision-making is incomparably worse. Calls for more participation do not attain general consent, as if we had learned that these procedures are as necessary as they are limited. The universe of organized protests frequently reflects artificial polarization and reproduces new forms of elitism. Those who have a greater interest in participation or a louder voice tend to end up imposing their views (Mansbridge 1983, 248). Scholars claim that those who generally participate the most are the rich and those with higher educational levels (Pattie / Seyd / Whiteley 2004). On the internet, as in other areas of society, people's abilities and possibilities for participation are distributed very unevenly, and institutions need to keep this in mind. In spite of our digital enthusiasm, on-line forums, for example, are characterized by great homogeneity and a greater presence of extremist positions. Just as politics has become professionalized, so too have protests and activism. At times, it is not easy to differentiate this type of involvement and the lobbying that represents a small minority. Even when lobbying defends interests that have not received a lot of attention, they are issues to which the most privileged do pay attention.

In general, direct democracy is attractive for the passive citizen, in other words, for those who are not much interested in exposing their opinions and interests in front of others in the public sphere and who prefer plebiscitary decision-making where they can assert their will in the political system without filters or deliberative modulations. Direct democracy and plebiscitary decision-making are instruments of an apolitical nature, and if they enjoy greater prestige than they deserve, it is because they are a part of that general tendency toward democracy without politics that characterizes our societies.

Plebiscites are as important in a democracy as they are incapable of replacing profound and open debates. Plebiscites are worse than representative relationships at reflecting the plurality of opinions and interests of a society. This imprecision is due to the fact of reducing decision-making procedures to binary possibilities. Within each camp, there are many heterogeneous positions that only coincide in the yes or no. In this way, direct democracy acts in a less 
representative manner than representative procedures of opinion making. Paradoxically, technocrats and the partisans of direct democracy argue that reducing a problem to a binary code makes the solution more transparent and less ideological, but both groups simplify the space of the game of politics, reduce the possibilities of political creativity and prevent the free use of nuances.

Let us think for a moment about the meteoric journey of the concept of transparency, in which we can find, in addition to unquestionable assets, some anti-political results. Let us allow its virtues to be trumpeted general acclaim; I would, however, like to point out the anti-political backdrop behind some of the ways in which it is demanded, which imply that the whole problem of politics consists of politicians hiding something whose revelation would resolve our problems. I wish it were so. The political system is more banal reality than secret-monger and, even if it revealed its private affairs to us, we could not completely dispel the uncertainties with which we are surrounded. The indirect result of this way of thinking is to give the impression that politics has to do with objectivity and evidence, a place where there is, in the end, nothing to discuss. Understood in this fashion, transparency is a concept that recalls the pre-political demand of objective facts. This objectivist prejudice is very widespread on both extremes of the ideological spectrum; it is shared by technocrats and libertarians, the defenders of the authority of experts and those who maintain that the people are never mistaken, those who trust everything to the self-regulation of the markets or to the wisdom of the crowd. A completely transparent space would be one that is completely depoliticized.

\section{The Great Rift}

Political societies have a very particular dynamic that we must understand correctly in order to avoid mistaken analyses. Traditional political forces, whether establishment or mainstream, want to administer the principle of reality, which they read in ways that are essentially different. This is the arena in which right and left debate. At times of crisis, this difference is reduced, as is logical, since crises diminish options and force the sober management of promises. When this happens, a good portion of society becomes disoriented or irritated, and phenomena appear where it is no longer a question of choosing between existing possibilities, but rather of impugning the range of options presented to us. There are new differentiations and an explosion of forces that ignore the principle of reality and attempt only to manage the pleasure principle.

The tragedy of contemporary politics is that those who have some responsibility - in other words, both the electorate and those elected - are continually forced to choose between rationality and populism. For the representatives, the first of these is not understood and makes reelection impossible, while the second places political stability in danger but is socially lauded. Those who govern frequently confront the dilemma of doing what citizens expect from their governments or what they are required to do. There have been so many political decisions adopted in the midst of this type of dilemma. That is the drama that politicians tend to reference: they know what they should do but they do not know how to be reelected if they do it.

This situation has altered the classical framework of ideological identification and its corresponding antagonism. Another axis is being superimposed on the right-left axis that confronts, in the broad sense, populists and technocrats; there are right- and left-wing versions in both categories. The new ideological spectrum can be explained by the diverse combinations of these four sensibilities. What we have is basically technocrats on the right and on the left, and populists on the right and left, giving way to alliances and antagonisms that are not intelligible from the classical ideological polarization. The new polarization that is brandished is one that confronts the elite with the general population, thus understanding society to be divided into two homogeneous groups.

This is, in my opinion, what was revealed in Spain in the 2014 European elections and explains the success of a political party that defines itself as people who Can in the face of those who administer limitations (I am specifically referring to the emergence of the Podemos [We Can] movement in Spain). The classical parties have governed and are going to govern, which means that they know about the limits of government and the extent to which unfulfilled promises take their toll; they may hate their adversaries, but they are also conscious that they will end up having to count on them for numerous matters; they know that they represent the people but that they are not the people, because in a democracy we can only attempt to speak in the name of the people in a representative fashion, in other words, without monopolizing it, in the midst of a plurality of voices and constantly exposed to the verification of that authority.

I believe that this is the great novelty, the new rift (although it is in no way unprecedented in the history of politics): the excision of responsibility and possibility. In contrast with what is often repeated, it is not so much a rebellion stemming from the alienation between unhearing elites and the innocent masses who disdain their representatives, as all the polls that point to the political class as our primary problem seem to claim. These new actors fill the stage with a language that contrasts with the calculated cardboard-like quality of traditional discourses, which has an unquestionable appeal for a large portion of the electorate. But, more than anything else, there is the appearance of a multitude of promises that become more attractive as they move further and further away from any plan of feasibility. Accusing them of being naïve 
is a sort of disparagement that makes no sense in the open space of a democratic society; the only inexperience that defines them is that they do not know how difficult it is to be reelected, and this experience is what gives political actors maturity.

The appearance of the new is as ancient as humanity itself. Only a lack of memory explains our bewilderment or excessive enthusiasm in the face of this rift that forms a part of the old cycle of our democracies. This unpredictable human history teaches us that everything that emerges also awaits contradiction, which stalks it as it does all mortals. History continues, and it is driven by a succession of promises and disappointments. Audacious promises are welcome, because our political systems require these jolts to show that no one can block the path to new actors and unusual agendas. It is better for them to work within political institutions than to protest indignantly at the margins. Because politics is a pathway that sooner or later leads all of us to reality, which we will always interpret differently, a pathway that, as an environment that conditions us and that we share with others, is always somewhat limiting. Politics is the place where each of us manages that frustration the best we can.

\section{A defense of Indirect Democracy}

Representative democracies have two enemies today: the accelerated world and the predominance of globalized markets on the one hand, and the hubris of the citizens on the other; in other words, the ambivalence of a people that politics should obey, of course, but whose politically rather unarticulated demands are often contradictory, incoherent, and dysfunctional. It is taboo to mention this second danger because many members of the political class and those who write about politics tend to worship the people, and do not charge them with any responsibility. Few speak about "democratic" threats to democracy, those that stem from public opinion polls, participation, exaggerated expectations, or transparency. In noting this lack, I am not attempting to invalidate the principle that people are the only sovereign in a democracy; I am simply emphasizing the fact that representative democracy is the best invention we have come up with to reconcile, though not without tensions, that principle with the complexity of political affairs. Even if it sounds paradoxical, there is no system other than indirect and representative democracy when it comes to protecting democracy from the citizenry, against their immaturity, weakness, uncertainty and impatience.

Some authors have called attention to this paradox in a provocative fashion: Philip Pettit, when clarifying how he understands republicanism: "democracy is too important to be left to the politicians, or even to the people voting in referendums" (2001, 746); Fareed Zakaria stating that "what we need in politics today is not more democracy but less" $(2003,248)$ or Bryan Caplan asserting that "democracy fails because it does what voters want" $(2008,3)$. Other theorists propose a classification of contemporary democracy — along the lines of classic republicanism - as a mixed government, as a type of mechanism that combines democratic and non-democratic components (Manin 1997, 237). Democracy is not the presence of citizens in places where decisions are made, but the fact that elective institutions and those elected can be judged by the citizenry.

The anti-establishment power of the "negative sovereign" is in no position to replace constructive power. It can politicize the public space in an isolated fashion by expressing indignation and staying on the margin of any construction of responsibility. Deep down, our democracy without politics has enthroned the citizens as independent evaluators who see themselves outside of any political arena, like consumers. Open societies have unleashed the liberties of consumers to such an extent that politics is also considered from the point of view of the client, who is willful, impatient, demanding ... The ideal of popular sovereignty has been transformed into a "sovereignty of the consumer." "The growing number of boycotts, expressions of dissatisfaction and other forms of activism seem to be currently driven by a consumer sentiment and there is a danger that activism will adopt the form of a lifestyle-statement rather than a serious commitment [...]. Activism seems to be nothing but a refined form of consumerism for those who are well-intentioned, who are allowed to access public resources and decision-making processes" (Stoker 2006, 88). However, does this figure use up all the democratically responsible critical potentiality inscribed in the concept of citizenship?

When we complain that the markets condition politics excessively, we should not lose sight of the fact that this conditioning is not limited to global financial markets but is also verified in the relationships between representatives and those who are represented. At every level, on the global and the domestic plane, the power of consumers is greater than that of voters.

When the logic of the sovereign consumer is established in politics, politics tends to melt with the immediacy of the short term. Politics is especially vulnerable to this, given the permanent electoral contest and the weight of public opinion, which has an ever shorter time-span because of the growing importance of polls and surveys, which allow us to attend to the demands of the present moment. Politics is enormously weakened if it is not capable of introducing other criteria to balance the possible tyranny of the present. If the institutions of representative democracy serve any purpose, it is to establish procedures that at least make debate possible, as well as the consideration of alternatives and constitutional guarantees. A democracy cannot function well if there are no institutions of indirect democracy that serve 
as regulating, referring, or judicial authorities (which tend to deteriorate when they remain in the hands of the parties), if the dimension of delegation that any government should have were completely suppressed (which is compatible, of course, with that delegation being limited in time and being held accountable); if the public opinion at any time is imposed on other expressions of popular will that are less instantaneous and more extended in time... This is most likely one of the problems that makes politics so dysfunctional and leads to so many irrational situations (Innerarity 2012). Politics must free itself of the "demoscopic fear" (Habermas 2012), without giving way to elitist and technocratic arrogance.

To respond to this incapacity and to the blockades generated by some demoscopic forms of government, political systems have been generating a series of procedures, sometimes in a furtive fashion. There is a well-known process of depoliticization that is due to the fact that there are increasing numbers of functions, responsibilities, and decisions that are directed toward spheres that are non-governmental, parastatal, hybrid, regulatory, transnational, non-majority, independent, or judicial, that are beyond the reach of democratic elections and supervision. The European Union is one of the institutions that fulfills that function. The idea of "quasi-governments" (Koppell 2003) or the increase of the "non-elected" responds to this new reality, in what constitutes a new division of power (Vibert 2007). There are other versions of this "functional depoliticization": an epistemic correction of procedural democracy to introduce expert knowledge into our decisions in some way (Estlund 2009), the proposal of depoliticizing certain institutions such as bureaucratic practices or the negative power of judges in the face of partisanship (Rosanvallon 2008), or the defense of a deliberative space depoliticizing some questions (Pettit 2001). There is also the fact that those who govern increase their discretional capacity and their powers of intervention - even their very possibility of acting — by privatizing or by emergency procedures. I will not make a judgment here about whether these forms of displacing power are justified o not; I am simply noting that there is a displacement of power toward locations less subject to public scrutiny and control and that this displacement is not always motivated by bad intentions, but by functional necessities. Paradoxically, while our political systems do not introduce into their own functioning a perspective that overcomes electoral short-sightedness, we will be promoting this systemic cunning that we later lament as lacking democratic legitimacy.

The polls say that politics has become one of our principal problems, but I wonder whether this opinion expresses nostalgia for the politics of the past, a criticism of its mediocrity, or anti-political scorn toward something whose logic has not been fully understood. In any case, we citizens could criticize with more authority if we would put the same effort into educating ourselves and into personal engagement. And perhaps then we would realize that we are in the paradoxical situation where no one entrusts politics with those things that only politics could resolve.

\section{References}

Budge, I. (1996). The New Challenge of Direct Democracy, Cambridge: Blackwell.

Caplan, B. (2008). The Myth of the Rational Voter: Why Democracies Choose Bad Politics, Princeton University Press.

Crenson, M., \& Ginsberg, B. (2002). Downsizing Democracy: How America Sidelined its Citizens and Privatized its Public, Baltimore: John Hopkins University Press.

Crouch, C. (2004). Post-democracy, Cambridge: Polity.

Dahlgreen, P. (2013). The Political Web. Media, Participation and Alternative Democracy, New York: Palgrave Macmillan. https://doi.org/10.1057/9781137326386

Dalton, R. (2004). Democratic Challenges - Democratic Choices. The Erosion of Political Support in Advanced Industrial Democracies, Oxford University Press. https://doi.org/10.1093/acprof:oso/9780199268436.001.0001

Estlund, D. (2009). Democratic Authority: A Philosophical Framework, Princeton University Press. https://doi.org/10.1515/9781400831548

Habermas, J. (2012). Zur Verfassung Europas. Ein Essay, Berlin: Suhrkamp.

Habermas, J. (2013). Im Sog der Technokratie, Berlin: Suhrkamp.

Hibbing, J., \& Theiss-Morse, E. (2002). Stealth Democracy: Americans' Belief about How Government Should Work, Cambridge University Press. https://doi.org/10.1017/CBO9780511613722

Innerarity, D. (2012). The Future and Its Enemies, Redwood City: Stanford University Press.

Koppell, J. (2003). The Politics of Quasi-Government: Hybrid Organizations and the Dynamics of Bureaucratic Control, Cambridge University Press.

Laclau, E., \& Mouffe, C. (1991). Hegemonie und radikale Demokratie. Zur Dekonstruktion des Marxismus, Wien: Passagen.

Manin, B. (1997). The Principles of Representative Government, Cambridge University Press. 
Mansbridge, J. (1983). Beyond Adversary Democracy, Chicago University Press.

Mouffe, C. (2013). Agonistics: Thinking The World Politically, London / New York: Verso.

Norris, P. (2002). Democratic Phoenix. Reinventing Political Activism, Cambridge University Press. https://doi.org/10.1017/CBO9780511610073

O'Toole, T., Marsh, D., \& Jones, S. (2003). Political Literacy Cuts Both Ways: The Politics of Non-Participation among Young People, Political Quarterly, 74(3), 349-360. https://doi.org/10.1111/1467-923X.00544

Pattie, C., Seyd, P., \& Whiteley, P. (2003). Civic Attitudes and Engagement in Modern Britain, Parliamentry Affairs, 56, 616-633. https://doi.org/10.1093/pa/gsg106

Pettit, P. (2001). Deliberative Democracy and the Case for Depoliticizing Government, University of NSW Law Journal $58,724-746$.

Rosanvallon, P. (2006). La contre-démocratie: la politique à l'âge de la défiance, Paris: Seuil.

Rosanvallon, P. (2008). La légitimité démocratique: Impartialité, reflexivité, proximité, Paris: Seuil.

Stoker, G. (2006). Why Politics Matter. Making Democracy Work, Basingstoke: Palgrave Macmillan.

Vibert, F. (2007). The Rise of the Unelected. Democracy and the New Separation of Powers, Cambridge University Press. https://doi.org/10.1017/CBO9780511491160.002

Vihinen, L., \& Lee, H. Y. (2004). "Fair Trade and the Multilateral Trading System", OCDE Trade Directorate, Paris: OCDE.

Zakaria, F. (2003). The Future of Freedom: Illiberal Democracy at Home and Abroad, New York: Norton.

\section{Copyrights}

Copyright for this article is retained by the author(s), with first publication rights granted to the journal.

This is an open-access article distributed under the terms and conditions of the Creative Commons Attribution license which permits unrestricted use, distribution, and reproduction in any medium, provided the original work is properly cited. 